\title{
Pendampingan Guru BAIK (Belajar, Aspiratif, Inklusif, dan Kontekstual)
}

\author{
${ }^{1}$ Yuntawati, ${ }^{2}$ Lalu Abdul Aziz, ${ }^{3}$ Wiwin Agustin \\ ${ }^{1}$ Universitas Pendidikan Mandalika. Pemuda No. 59A, Mataram, Indonesia 83125 \\ ${ }^{2}$ Universitas Nahdlatul Ulama (UNU) NTB, Jl. Pendidikan No. 06 Mataram, Indonesia 83125 \\ ${ }^{3}$ SMAN 3 Sumbawa Besar, Jl. Cendrawasih No. 139 Sumbawa Besar, Indonesia 84316
}

\section{Email Korespondensi: yuntawati@ikipmataram.ac.id}

\begin{tabular}{|c|c|}
\hline$A r t$ & ract \\
\hline Published: 2020-06-30 & \multirow{2}{*}{$\begin{array}{l}\text { Teacher Assistance BAIK (Learning, Aspirational, Inclusive, and } \\
\text { Contextual). The Indonesia Indonesia Partnership INNOVATION pilot } \\
\text { program has partnered with several Universities in NTB in collaboration with } \\
\text { the Ministry of Education and Culture, the NTB Provincial Government and the } \\
\text { Australian Government targeting } 25 \text { elementary level partner schools in North } \\
\text { Lombok and Sumbawa districts. The purpose of PKM activities is to improve } \\
\text { the quality of learning of elementary school teachers in North Lombok district. } \\
\text { The methods used in this activity are workshops, training and mentoring. The } \\
\text { results of this activity are 1) participants understand the techniques of } \\
\text { identifying student learning difficulties and identification of students' } \\
\text { aspirations, 2) participants understand how to analyze student learning } \\
\text { difficulties, 3) participants can design learning tools based on student learning } \\
\text { difficulties, and 4) participants can implement learning tools that are has been } \\
\text { designed. Mentoring activities need to be carried out continuously so that BAIK } \\
\text { teachers can really implement the vision and mission of BAIK teachers. }\end{array}$} \\
\hline $\begin{array}{l}\boldsymbol{K} \\
m \\
B\end{array}$ & \\
\hline & \\
\hline & \multirow{2}{*}{$\begin{array}{l}\text { Program rintisan INOVASI Kemitraan Australia Indonesia menggandeng } \\
\text { beberapa Perguruan Tinggi di NTB bekerjasama dengan Kemendikbud, } \\
\text { Pemprov NTB, dan Australian Government menyasar } 25 \text { sekolah mitra tingkat } \\
\text { SD di kabupaten Lombok Utara dan Sumbawa. Tujuan kegiatan PKM untuk } \\
\text { meningkatkan kualitas pembelajaran guru-guru SD di kabupaten Lombok Utara. } \\
\text { Metode yang digunakan dalam kegiatan ini adalah workshop, pelatihan dan } \\
\text { pendampingan. Hasil dari kegiatan ini adalah 1) peserta memahami teknik } \\
\text { mengidentifikasi kesulitan belajar siswa dan identifikasi aspirasi siswa, 2) } \\
\text { peserta memahami cara menganalisis kesulitan belajar siswa, 3) peserta dapat } \\
\text { merancang perangakat pembelajaran berdasarakan kesulitan belajar siswa, dan } \\
\text { 4) peserta dapat mengimplementasikan perangkat pemebelajaran yang telah } \\
\text { dirancang. Kegiatan pendampingan perlu dilakukan secara kontinu agar guru- } \\
\text { guru BAIK benar-benar dapat mengimplemetasikan visi dan misi dari guru } \\
\text { BAIK. }\end{array}$} \\
\hline & \\
\hline
\end{tabular}

Sitasi:Yuntawati, Aziz A.L., \& Agustin W. (2020) Pendampingan Guru BAIK (Belajar, Aspiratif, Inklusif, dan Kontekstual) Sasambo: Jurnal Abdimas (Journal of Community Service). 2(2), 70-79. DOI : $\underline{10.36312 / \text { sasambo.v2i2.213 }}$

\section{PENDAHULUAN}

Dalam mengikuti proses pembelajaran di kelas, tidak sedikit siswa yang mengalami kesulitan beajar. Kesulitan belajar tersebut dapat menampakkan diri dalam bentuk kesulitan mendengarkan, berpikir, berbicara, menulis, mengeja (Abdurrahman, 2012) atau pada berhitung dapat muncul dalam kesulitan mengingat kembali, memahami, menginterpretasi informasi, memahami symbol dan memanipulasinya, mengabstraksi, menggeneralisasi, 
menalar, memecahhkan masala, dan masih banyak lagi (Widdiharto, 2011). Acapkali kesulitan belajar siswa tersebut tidak ditindaklanjuti dengan baik oleh guru yang mengajar. Bisa jadi guru betul-betul tidak menyadari adanya kesulitan siswa tersebut. Tetapi bisa juga sebetulnya kesulitan belajar siswa tersebut terlacak oleh guru, namun guru tersebut merasa tidak mempunyai cukup waktu untuk menindaklanjutinya, atau guru merasa kurang mampu untuk mengatasi masalah yang muncul dan yang terakhir adalah mungkin guru tersebut tidak peduli terhadap kesulitan belajar yang dialami siswanya.

Kemampuan mengidentifikasi kesulitan belajar siswa sangat penting untuk meningkatkan kualitas mengajar, sekaligus mengatasi kesulitan belajar tersebut. Kemampuan mengidentifikasi kesulitan belajar siswa, membantu guru untuk memahami: 1) Jenis-jenis kesulitan siswa, 2) daya serap kemampuan siswa terhadap materi/topik yang diajarkan guru, dan 3) cara berpikir/bernalar siswa. Identifikasi kesulitan belajar siswa tersebut menjadi langkah awal untuk menyusun rencana perbaikan, baik untuk mengatasi kesulitan belajar siswa, atau secara umum untuk peningkatan pembelajaran di kelas, dan pelaksanaan remidi. Selain kesulitan belajar siswa, guru juga dituntut peka untuk mengidentifikasi aspirasi siswa di kelas. Aspirasi siswa sering dihubungkan dengan harapan, keinginan, dan kemampuan membangun pekerjaan di masa depan (Quaglia dan Fox, 2011). Selanjutnya para guru bisa menjadikan hasil identifikasi kesulitan belajar siswa dan aspirasi siswa ini untuk menentukan tindakan atau metode yang akan dipakai untuk mengatasi kesulitan belajar siswa. Tindakan atau metode pembelajaran dituangkan dalam sekenario pembelajaran. Dalam sekenario pembelajaran selain memuat sintaks metode yangditetapkan juga perlu dicantumkan proses assessment untuk mengukur ketercapaian hasil belajar siswa.

Berdasarkan observasi selama pra-rintisan program INOVASI, ditemukan bahwa provinsi NTB mengalami tantangan besar dalam pendidikan yaitu hasil belajar siswa rendah akibat kurangnya kemampuan literasi siswa. Teridentifikasi pula bahwa guru memiliki keterbatasan dalam kegiatan pembelajaran literasi di kelas awal. Selain itu, materi pembelajaran yang konvensional, pengelolaan kelas yang minimalis, dan managemen pembelajaran yang kurang interaktif dan menarik.

Program INOVASI sebagai penyelenggara kegiatan didukung oleh pemerintah kabupaten menyelenggarakan serangkaian kegiatan rintisan yang terangkum dalam kegiatan guru BAIK (Belajar, Aspirasi, Inklusif, dan Kontekstual) guna meningkatkan hasil belajar siswa melalui pengembangan kualitas pembelajaran. Untuk itu diperlukan tenaga ahli yang menguasai pengetahuan tentang proses belajar mengajar. Dalam hal ini Dosen dari beberapa perguruan tinggi di NTB dan fasilitator baik tingkat daerah maupun tingkat nasional dipercaya pihak INOVASI sebagai tenaga ahli yang membantu tercapainya tujuan kegiatan.

Dalam kegiatan guru BAIK ini INOVASI melibatkan dosen sebagai dosen pendamping yang bertugas untukmendampingi para guru SD disetiap workshop dan selama implementasi hasil workshop. Pada kegiatan pendampingan ini para guru akan difasilitasi untuk mengenali berbagai strategi/cara untuk mengidentifikasi kesulitan belajar dan aspirasi siswa di kelas, menentukan metode pembelajaran yang tepat, menyusun sekenario pembelajaran dan assessment yang digunakan. Fatimah dan Sari (2018) mengemukakan bahwa strategi yang terencana memegang peranan penting dalam proses pembelajaran. Strategi erat kaitannya dengan teknis dalam melaksanakan pembelajaran tersebut.

Penelitian tentang penerapan berbagai macam strategi pembelajaran telah banyak dilakukan, diantaranya penelitian yang dilakukan (Nissa \& Yuntawati, 2017) pembelajaran Self-Questioning dengan scaffolding memiliki pengaruh terhadap kemampuan pemecahan masalah dan kemandirian mahasiswa. Hal ini didukung oleh hasil penilaian diri dan pengamatan keterlaksanaan perkuliahan yang menunjukkan hasil sebesar $57,15 \%$ aspek kemandirian mahasiswa pada kategori "Baik" dan 42,85\% aspek kemandirian mahasiswa pada kategori "Sangat Baik"; Nissa, (Sanapiah, \& Yuntawati, 2018) melalui pembelajaran 
ELPSA (Experience, Language, Pictorial, Symbolic, Application) untuk Meningkatkan Literasi Matematika Siswa menyimpulkan bahwa ada perbedaan hasil tes secara siginifikan antara sebelum dan sesudah perlakuan dan berdasarkan temuan penelitian maka pembelajaran ELPSA dapat dirujuk sebagai salah satu pendekatan untuk meningkatkan literasi matematika siswa; Wahyudi \& Hadaming (2019) menerapkan Strategi Pembelajaran Circuit Learning Terhadap Hasil Belajar Matematika Siswa. Berdasarkan analisis data diketahui bahwa peningkatan hasil belajar matematika siswa setelah di ajar dengan strategi Circuit Learning berada pada kategori sedang.

Berdasarakan uraian permasalahn di atas maka tim Pengabdian melakukan pendampingan guru BAIK dengan tujuan meningkatkan kualitas pembelajaran guru-guru SD di kabupaten Lombok Utara melalui program workshoop, pelatihan dan pendampingan.

\section{METODE}

\section{Solusi Permasalahan}

Solusi permasalahan pendidikan di daerah menitikberatkan pada pendekatan 'solusi lokal bagi permasalahan lokal' yang disebut Problem Driven Iteratif Approach (PDIA) melalui program Guru BAIK yang merupakan program rintisan INOVASI. Program INOVASI percaya bahwa keterlibatan dan peningkatan kapasitas SDM lokal merupakan cara tepat untuk meningkatkan mutu pendidikan di daerah.

Guru BAIK (Belajar, Aspiratif,, Inklusif, dan Kontekstual) merupakan pengejawantahan dari namanya: aspiratif,, inklusif, dan pembelajaran secara kontekstual. Dengan kata lain, guru-guru yang baik adalah guru yang mau belajar dan bersedia menciptakan lingkungan pembelajaran yang inklusif dan kontekstual bagi para siswanya.

Kegiatan Guru BAIK terangkum dalam enam tahapan kegiatan. Keenam tahap Guru BAIK dilaksanakan melalui rangkaian empat workshop disertai dengan kegiatan pendampingan, diskusi publik, dan diseminasi. Dalam workshop satu dan dua, fasilitator INOVASI membantu guru mitra untuk mengidentifikasi masalah pembelajaran di kelas mereka, dan menyusun rencana aksi penelitian untuk lebih menjajaki masalah tersebut dan kemungkinan solusinya. Workshop ketiga dan keempat, guru mitra menerapkan rencana aksi mereka di kelas dan menerima pelatihan untuk mengembangkan metode pembelajaran dan asessment. Sebagai langkah terakhir, para guru mitra berbagi temuan dan pengalaman mereka melalui diskusi publik dan diseminasi.

\section{Metode \& Prosedur Pemecahan Masalah}

Kegiatan pengabdian kepada masyarakat yang berupa pendampingan kepada guru-guru sekolah dasar terorganisir dalam suatu rangkain kegiatan yang digambarkan pada diagram 1 berikut:
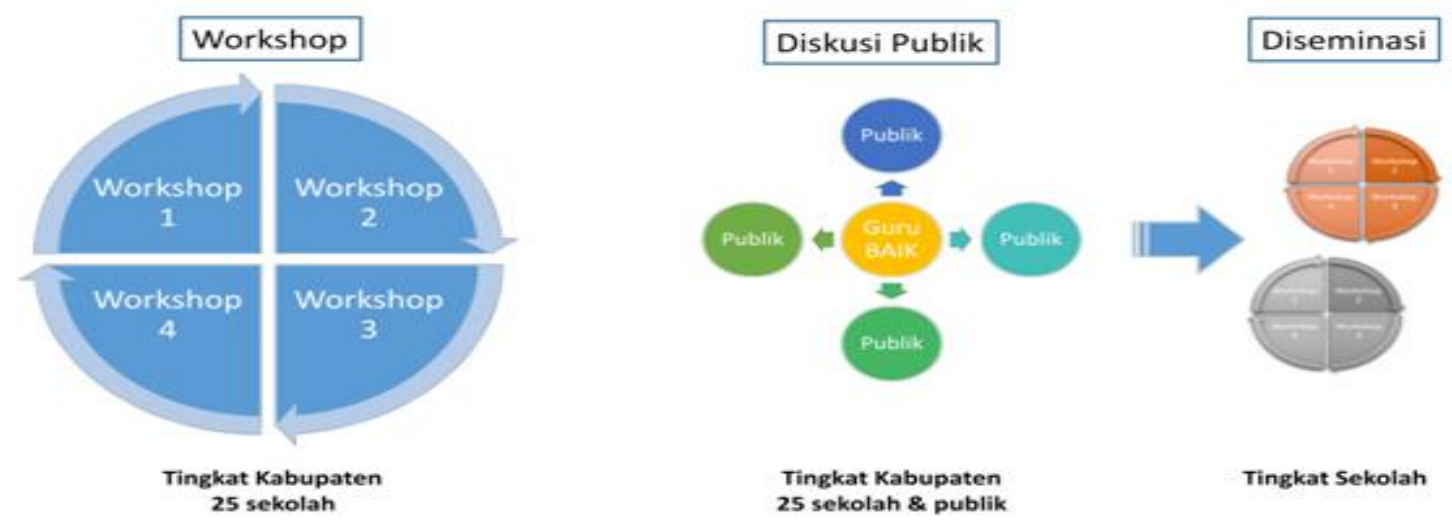

Gambar 1. Diagram Rangkaian Kegiatan Guru BAIK 
Lebih jelasnya rangkaian kegiatan workshop guru BAIK beserta tim pelaksana guru BAIK diperlihatkan oleh diagram 2 dan diagram 3 di bawah ini:

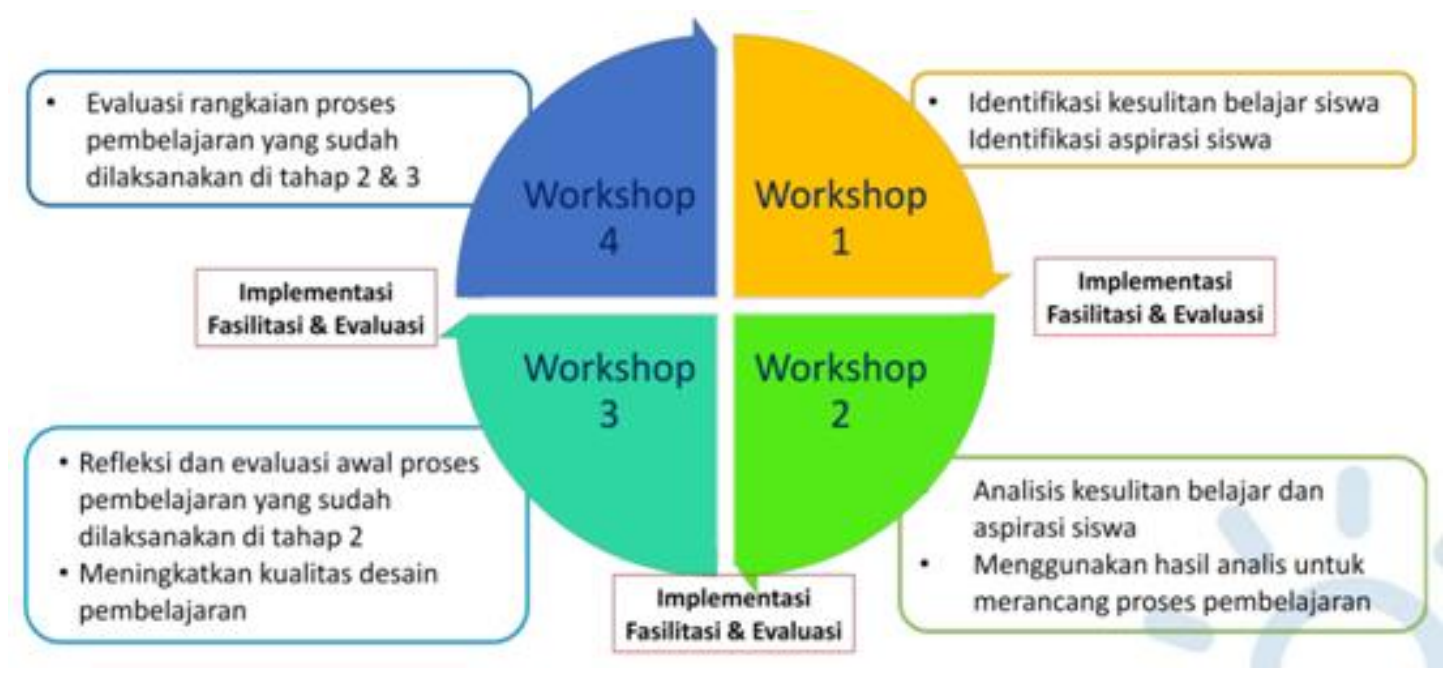

Gambar 2. Diagram Rangkaian kegiatan workshop guru BAIK

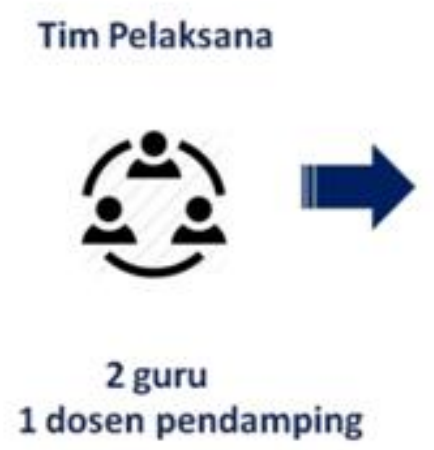

Tim Fasilitator

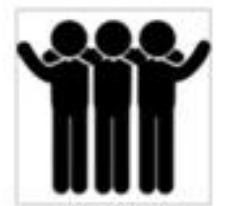

\section{Workshop}

Gambar 3. Diagram Tim guru BAIK

Dalam kegiatan guru BAIK ini INOVASI melibatkan dosen dari beberapa perguruan tinggi di NTB dan fasilitator baik tingkat daerah maupun tingkat nasional. Dosen dan fasilitator dibentuk dalam beberapa kelompok dimana masing-masing kelompok terdiri dari satu fasilitator nasional, dua fasilitator daerah dan dua dosen yang mendampingi dua guru SD yang berbeda. Subyek kegiatan pendampingan guru BAIK ini adalah guru-guru SD dari 25 sekolah mitra di kabupaten Lombok Utara dan Sumbawa, diantaranya adalah SDN 7 Pemenang Barat dan SDN 2 Gili Indah.

Pendampingan oleh Dosen dibatasi hanya selama kegiatan workshop dan implementasi di tingkat sekolah masing-masing. Selanjutnya kegiatan diskusi publik dan diseminasi ke sekolah lain dilanjutkan oleh fasilitator.

\section{Partisipasi Mitra}

Perwakilan guru-guru SD dari sekolah mitra berpartisipasi dalam semua rangkaian kegiatan workshop, diskusi piblik, dan diseminasi. Pada kegiatan workshop, guru mitra berpartisipasi dalam proses pelatihan penyusunan instrumen pembelajaran, dan implementasi instrumen pembelajaran di masing-masing sekolah. Pada kegiatan diskusi publik dimana guru mitra berbagi temuan dan pengalaman mereka. Diskusi Publik dihadiri warga 
masyarakat dan pemangku kepentingan di bidang pendidikan termasuk guru setempat, pengawas sekolah, pejabat Kabupaten, dan kepala sekolah, serta guru dari sekolah yang tidak berpartisipasi dalam program ini. Pada kegiatan diseminasi, guru mitra berpartisipasi menjadi tutor bagi kelompok guru di sekolah lain.

\section{HASIL DAN PEMBAHASAN}

Kegiatan pengabdian ini terangkai dalam dua tahapan yaitu workshop dan impementasi hasil workshop di tingkat sekolah pada satuan pendidikan.

\section{A. Workshop}

Kegiatan workshop dilaksanakan sebanyak empat kali. Tempat kegiatan workshop I dilaksanakan di Hotel Mina Tanjung Lampir danworkshop II sampai dengan IV di hotel Medana Bay Marina Teluk Dalam Kern - Medana Tanjung.

Tujuan kegiatan workshop ini adalah untuk memberikan pengetahuan dan pemahaman tentang strategi peningkatan kualitas pembelajaran kepada guru-guru SD di Kabupaten Lombok Utara. Adpun rincian kegiatan dalam setiap workshop diuraikan sebagai berikut:

1. Workshop 1

Workshop 1 berisi penyampaian materi tentang bagaimana cara mengidentifikasi kesulitan belajar siswa dan identifikasi aspirasi siswa oleh fasilitator nasional. Implementasi dari materi yang telah disampaikan dituangkan dalam lembar kegiatan identifikasi kesulitan belajar siswa dan identifikasi siswa yang dibagikan panitia penyelenggara kepada guru agar diisi sesuai dengan kondisi siswa sekolah masingmasing. Dosen bertugas mendampingi dan memfasilitasi guru-guru SD untuk mengenali berbagai strategi/cara untuk mengidentifikasi kesulitan belajar dan aspirasi siswa di kelas. Selama proses mengidentifikasi kesulitan belajar siswa, guru kurang bisa membedakan antara kesulitan belajar siswa dengan kesulitan mengajar siswa. Sebagai contoh, guru menyebutkan bahwa 'siswa sulit diarahkan', atau 'siswa sulit diatur'. Guru juga kesulitan menyebutkan aspirasi siswa karena selama ini tidak pernah ditanyakan ke siswa, sehingga apa yang dituliskan guru hanya berdasarkan apa yang diingat saja. Lembar kegiatan selanjutnya dikumpulkan dan dievaluasi oleh fasilitator nasional. Selanjutnya guru diberi tugas mengidentifikasi kesulitan belajar dan aspirasi siswa di kelas secara langsung sebelum workshop 2 dilaksanakan.

2. Workshop 2

Workshop 2 berisi penyampaian materi tentang bagaimana cara menganalisis kesulitan belajar siswa dan aspirasi siswa dan menggunakan hasil analisis untuk merancang proses pembelajaran oleh fasilitator nasional. Sebagaimana pada workshop 1, implementasi dari materi yang telah disampaikan dituangkan dalam lembar kegiatan analisis kesulitan belajar siswa dan aspirasi siswa yang dibagikan panitia penyelenggara. Hasil identifikasi yang dilakukan guru masih sangat umum. Dosen membantu guru dalam proses mereduksi hasil identifikasi hingga mengerucut pada kesulitan belajar dan aspirasi siswa di satuan pendidikan. Guru tidak banyak mengalami kesulitan dalam menganalisis kesulitan belajar dan aspirasi siswa. Lembar kegiatan kemudian dikumpulkan dan dievaluasi oleh fasilator nasional.

Kegiatan dilanjutkan ke tahap merancang proses pembelajaran. Dosen bertugas mendampingi dan memfasilitasi guru-guru SD untuk menentukan metode pembelajaran yang tepat, menyusun sekenario pembelajaran dan assessment. Pada kegiatan ini guru cukup kesulitan menentukan metode apa yang tepat untuk digunakan dalam pembelajaran karena pengetahuan guru dalam hal ini sangat kurang. Meskipun dosen sudah memperkenalkan beberapa metode pembelajaran untuk dicobakan tetapi guru masih kesulitan untuk memikirkan media pembelajaran yang cocok dan mampu diadakan oleh guru. Para guru selanjutnya diminta untuk mencobakan rancangan pembelajarannya di 
kelas mereka masing-masing dan melakukan observasi pelaksanaan pembelajaran sebelum kegiatan workshop 3 dilaksanakan .

3. Workshop 3

Workshop 3 berisi kegiatan refleksi dan evaluasi awal implementasi rancangan proses pembelajaran yang telah dibuat pada saat workshop 2. Panitia meminta beberapa guru dari sekolah yang berbeda sebagai perwakilan untuk menyampaikan hasil implementasinya. Selanjutnya fasilitator nasional merefleksi dan mengevaluasi apa yang dipresentasikan para guru tersebut. Kegiatan kemudian dilanjutkan dengan proses pendampingan oleh dosen untuk meningkatkan kualitas desain pembelajaran yang telah dibuat para guru. Dosen juga mendampingi guru dalam membuat RKTL (Rencana Kegiatan Tindakan Lapangan) yang berisi rencana semua tindakan yang akan dilakukan sebelum kegiatan implementasi desain pembelajaran yang dilaksanakan setelah workshop 3 dan sebelum workshop 4 dilaksanakan.

4. Workshop 4

Whorshop 4 dilaksanakan setelah kegiatan impementasi hasil workshop di tingkat sekolah pada satuan pendidikan, dimana dosen melakukan pendampingan proses kegiatan pembelajaran langsung ke sekolah. Dalam hal ini kami mendapat tugas mendampingi guru matematika dari SDN 7 Pemenang Barat dan SDN 2 Gili Indah. Workshop 4 berisi evaluasi rangkaian proses pembelajaran yang sudah dilaksanakan.

Kegiatan pendampingan sebagai implementasi hasil workshop I dan II dilakukan melalui email dan Whatshap, dimana kegiatan yang harus dilakukan guru adalah mengidentifikasi kesulitan belajar dan aspirasi siswa serta menganalisis kesulitan belajar siswa dan aspirasi siswa di sekolah masing-masing. Untuk dapat mengidentifikasi kesulitan belajar siswa, guru melakukan beberapa cara antara lain menyebarkan angket kesulitan belajar untuk diisi oleh siswa, melakukan wawancara mendalam dengan siswa, dan melakukan observasi selama proses belajar mengajar berlangsung. Hal ini sejalan dengan pendapat Alang (2015) bahwa pelaksanaan identifikasi dapat dilakukan dengan memperhatikan laporan guru kelas, hasil tes intelegensi, atau melalui instrumen informal, misalnya dalam bentuk observasi, tes hasil belajar, tes identifikasi faktor-faktor penyebab kesulitan belajar.

Rangkaian kegiatan workshop ini sangat membantu guru-guru SD mengetahui dan memahami pengetahuan tentang pengelolaan kelas yang dapat meningkatkan kualitas pembelajaran, tidak hanya dalam teori tapi juga implementasi langsung.

\section{B. Impementasi Hasil Workshop Di Tingkat Sekolah Pada Satuan Pendidikan.}

Kegiatan pendampingan impementasi hasil workshop di tingkat sekolah pada satuan pendidikan oleh dosen dan fasilitator nasionaldilakukan setelah kegiatan workshop 3. Dosen pendamping dan fasilitator nasional datang ke SDN 7 pemenang Barat dan SDN 2 Gili Indah setelah melakukan komunikasi dengan guru untuk menyepakati waktu pendampingan. Berikut hasil kegiatan pendampingan di SDN 7 Pemenang Baratdan SDN 2 Gili Indah:

1. Pendampingan Guru di SDN 7 Pemenang Barat

Kegiatan pendampingan ini dimaksudkan untuk memastikan RKTL yang dibuat guru terlaksana dengan baik. Hal pertama yang dilakukan adalah melakukan observasi proses pembelajaran yang dilakukan guru secara langsung di kelas. Materi yang disampaikan adalah bangun datar beraturan. Metode pembelajaran yang digunakan adalah tutor sebaya berbantuan media pembelajaran berupa puzzle yang berbentuk segitiga siku-siku, segitiga sama kaki, segitiga sama sisi, persegi, persegi panjang, belah ketupat, layang-layang, jajar genjang, dan trapesium. Sugiyati (2016) mengungkapkan bahwa media pembelajaran dapat menumbuhkan ketertarikan positif siswa terhadap pelajaran dan menimbulkan kemauan untuk belajar. 
Bersama Fasilitator Nasional, Dosen Pendamping melakukan observasi terhadap pelaksanaan skenario pembelajaran. Selama observasi, selain mengisi lembar observasi pembelajaran yang diberikan INOVASI, berdasarkan catatan-catatan yang dibuat Dosen Pendamping ditemukan beberapa hal yang perlu mendapat perbaikan dalam pelaksanaan pembelajaran, antara lain:

a. Guru tidak memberikan umpan balik, baik secara lisan maupun tulisan kepada siswa

b. Guru tidak memberi waktu kepada siswa untuk mempresentasikan hasil kerjanya

c. Guru tidak pernah memberi penghargaan atas kerja siswa, minimal berupa pujian.

Secara keseluruhan kegiatan yang direncanakan pada RKTL sebagai wujud dari implementasi hasil workshop III mencakup penyempurnaan skenario pembelajaran, pembuatan media pembelajaran, dan pengaplikasian skenario pembelajaran yang sudah disempurnakan berjalan cukup lancar.

Meskipun ada kendala dalam pelaksanaan RKTL, akan tetapi kendala yang dialami tidak terlalu signifikan.Hanya masalah pengadaan bahan untuk pembuatan media pembelajaran yang memakan waktu. Hal ini dikarenakan bahan-bahan yang diperlukan tidak semuanya dapat diperoleh di Pemenang. Media berupa bangun datar hanya bisa dicetak atau dibuat di Mataram, sehingga Guru harus pergi ke Mataram. Namun dengan kesungguhan dan kerja sama yang baik, semua yang direncanakan bisa terlaksana tepat waktu.

Berikut ini beberapa dokumentasi kegiatan pendampingan guru BAIK di SDN 7 Pemenang Barat:
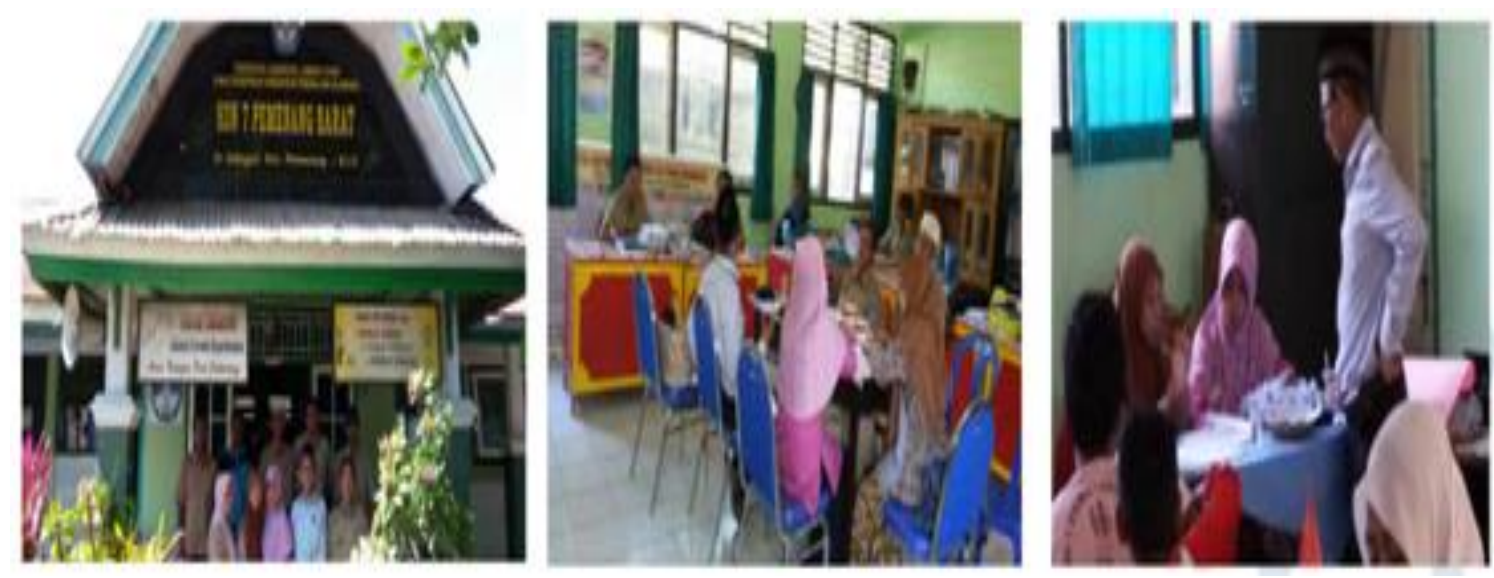

Gambar 5 . Kegiatan pendampingan oleh fasilitator dan dosen

\section{Pendampingan Guru di SDN 2 Gili Indah}

Sebagaimana kegiatan pendampingan di SDN 7 Pemenang Barat, kegiatan pendampingan di SDN 2 Gili Indah juga dimaksudkan untuk memastikan RKTL yang dibuat guru terlaksana dengan baik. Hal pertama yang dilakukan adalah melakukan observasi proses pembelajaran yang dilakukan guru secara langsung di kelas. Materi yang disampaikan adalah aritmetika sosial. Metode pembelajaran yang digunakan adalah diskusi kelompok berbantuan media cerita bergambar. Menurut Azhar Arsyad dalam Kamsiyatun (2016) bahwa media gambar meningkatkan daya tarik anak pada pembelajaran, membangkitkan minat dan perhatian anak, serta mempermudah anak dalam memahami materi pelajaran.

Bersama Fasilitator Nasional, Dosen Pendamping melakukan observasi terhadap pelaksanaan skenario pembelajaran. Selama observasi, selain mengisi lembar observasi pembelajaran yang diberikan INOVASI, berdasarkan catatan-catatan yang dibuat Dosen Pendamping ditemukan beberapa hal yang perlu mendapat perbaikan dalam pelaksanaan pembelajaran, antara lain:

a. Guru kurang bisa memanage waktu disetiap kegiatan pembelajaran 
b. Guru tidak memberikan umpan balik, baik secara lisan maupun tulisan kepada siswa

c. Mungkin dikarenakan guru yang mengajar bukan Guru inti yang seharusnya (Guru inti berhalangan karena sakit), maka Guru kurang bisa mengajak siswa untuk lebih berani bertanya.

Secara keseluruhan kegiatan yang direncanakan pada RKTL sebagai wujud dari implementasi hasil workshop III mencakup penyempurnaan skenario pembelajaran, pembuatan media pembelajaran, dan pengaplikasian skenario pembelajaran yang sudah disempurnakan berjalan cukup lancar.

Adapun kendala yang dihadapi guru di SDN 2 Gili Indah tidak jauh beda dengan kendala yang dihadapi guru di SDN 7 Pemenang Barat yaitu masalah pengadaan bahan untuk pembuatan media pembelajaran yang memakan waktu. Hal ini dikarenakan bahan-bahan yang diperlukan tidak semuanya dapat diperoleh di Gili Trawangan. Meskipun demikian secara keseluruhan pembelajaran sudah bejalan cukup baik, siswa pun cukup interaktif selama pembelajaran. Sehingga dapat disimpulkan bahwa metode pembelajaran dan media yang dibuat Guru dapat memotivasi siswa dalam belajar.

Kendala/hambatan/tantangan dalam setiap pembelajaran pasti selalu ada. Untuk dapat membantu kesulitan siswa terutama dalam hal belajar, kami para dosen pendamping dan fasilitator memberikan saran agar para guru memberikan scaffolding selama proses pembelajaran. Saye dan Brush (dalam Yuntawati, 2017) membedakan antara hard scaffolding dan soft scaffolding. Hard scaffolding mengacu pada bantuan statis yang dapat diantisipasi dan direncanakan terlebih dahulu berdasarkan jenis kesulitan siswa dengan tugas atau masalah. Sedangkan soft scaffolding mengacu pada pemberian bantuan dinamis dan spontan berdasarkan tanggapan peserta didik.

Berikut ini beberapa dokumentasi kegiatan pendampingan guru BAIK di SDN 2 Gili Indah:
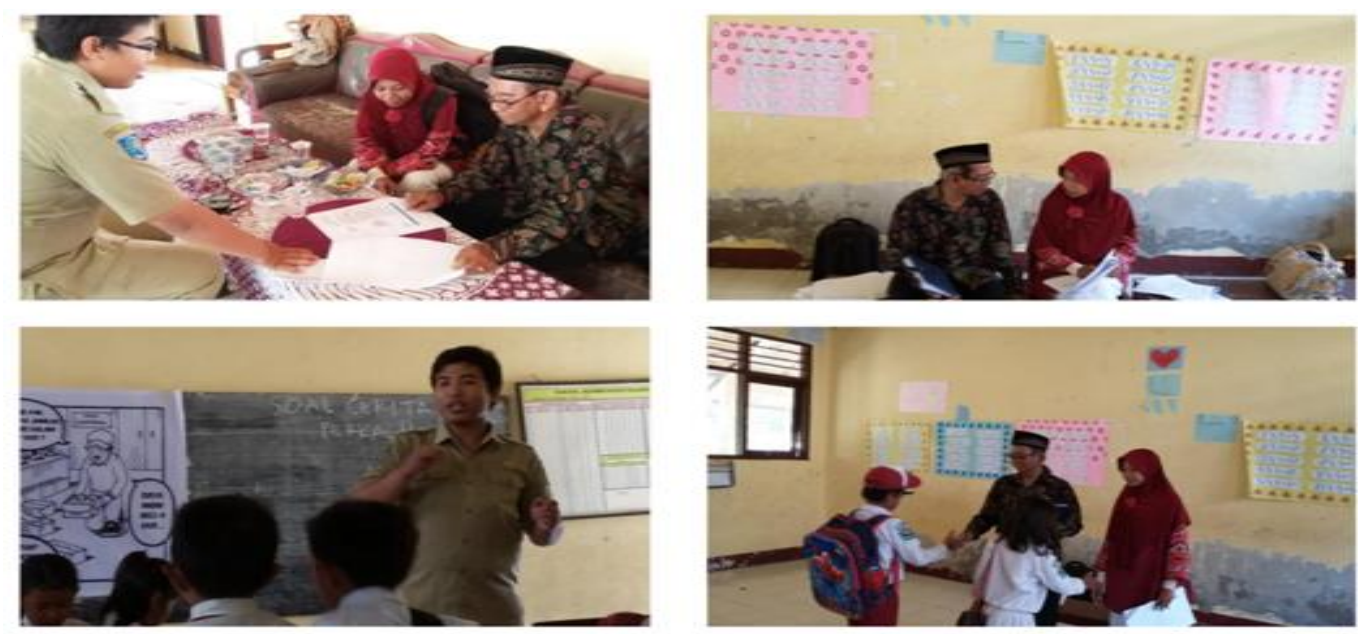

Gambar 2. Kegiatan pendampingan oleh fasilitator dan dosen

\section{KESIMPULAN}

Berdasarkan hasil pelaksanaan kegiatan pendampingan guru BAIK ini dapat ditarik kesimpulan bahwa:

1. Kegiatan pendampingan guru BAIK oleh dosen dapat memotivasi guru-guru SD akan pentingnya meningkatkan kualitas guru dengan terus belajar dan memahami karakteristik peserta didik

2. Kegiatan pendampingan guru BAIK oleh dosen sangat membantu guru-guru SD dalam mengetahui dan memahami bagaimana mengidentifikasi kesulitan belajar siswa dan aspirasi siswa, menentukan metode pembelajaran yang tepat berdasarkan hasil identifikasi 
kesulitan belajar siswa dan aspirasi siswa, menyusun sekenario pembelajaran dan assessment sehingga tujuan pembelajaran yang ditetapkan guru dapat tercapai

3. Melalui pendampingan guru BAIK ini, guru-guru SD mengetahui bahwa identifikasi kesulitan belajar siswa dapat dilakukan dengan berbagai macam cara antara lain, dengan menyebarkan angket kesulitan belajar untuk menggali kesuliatan belajar apa saja yang dirasakan siswa; melakukan wawancara mendalam untuk menggali lebih dalam aspirasi siswa; melakukan observasi kelas untuk mengetahui kecenderungan perilaku siswa dalam proses belajar mengajar.

\section{SARAN}

Berdasarkan temuan selama proses pendampingan guru BAIKdapat diberikan saran sebagai berikut:

1. Kepada tenaga ahli di bidang pendidikan agar dapat memperbanyak kegiatan-kegiatan yang dapat membantu guru-guru terutama guru SD dalam meningkatkan kualitas pembelajaran karena masih banyak guru-guru SD yang pengetahuan pengelolaan kelasnya kurang.

2. Untuk memperlancar kegiatan, baiknya diberikan terlebih dahulu pengetahuan tentang berbagai macam metode pembelajaran kepada guru agar para guru lebih mudah dan kaya wawasan dalam mengambil solusi atas kesulitan belajar yang dihadapi siswanya.

\section{UCAPAN TERIMA KASIH}

Ucapan terima kasih terutama kami tujukan kepada INOVASI yang telah melibatkan kami dalam kegiatan pendampingan guru BAIK ini dan telah memberikan dana pengabdian. Ucapan terima kasih juga kami sampaikan kepada Dekan FSTT Universitas Penidikan Mandalika, Kaprodi Pendidikan Matematika dan pihak-pihak yang membantu pelaksanaan pengabdian.

\section{DAFTAR PUSTAKA}

Abdurrahman, Mulyono. (2012). Pendidikan Bagi Anak Berkesulitan Belajar. Jakarta: PT. Rineka Cipta

Alang, H. M. S. (2015). Urgensi Diagnosis dalam Mengatasi Kesulitan Belajar. Al-Irsyad AlNafs, Jurnal Bimbingan Penyuluhan Islam, 2 (1), 1-14. Retieved fromhttp://journal.uin-alauddin.ac.id/index.php/Al-Irsyad_AlNafs/article/download/2557/2397

Fatimah, F. \& Sari, D. K. (2018). Strategi Belajar \& Pembelajaran dalam Meningkatkan Keterampilan Bahasa. Pena Literasi: Jurnal Pendidikan Bahasa dan Sastre Indonesia, $\quad 1 \quad$ (2), $\quad 108-113 . \quad$ Retieved from https://jurnal.umj.ac.id/index.php/penaliterasi

Kamsiyatun, K. (2016). Pemanfaatan Media Gambar untuk Meningkatkan Hasil Belajar Matematika Siswa Kelas IA SDN Sidomekar 08 Kecamatan Semboro Kabupaten Jember Tahun Pelajaran 2014/2015. Jurnal Pancaran, 5 (2), 91-102. Retieved from https://jurnal.unej.ac.id/index.php/pancaran/article/view/3023/2430

Nissa, I. C., Sanapiah, S., \& Yuntawati, Y. (2018). Peningkatan Literasi Matematika Melalui Pembelajaran ELPSA (Experience, Language, Pictorial, Symbol, Application). Prosiding Konferensi Nasional Penelitian Matematika dan pembelajarannya (KNKP) III 2018 (pp. 406-416). Surakarta, Indonesia: Pendidikan Matematika, Universitas Muhammadiyah Surakarta. Retieved fromhttps://publikasiilmiah.ums.ac.id/handle/11617/10232?show=full

Nissa, I. C., \& Yuntawati, Y. (2017). Pengaruh Pembelajaran Self-Questioning dengan Scaffolding Terhadap Kemampuan Pemecahan Masalah dan kemandirian Mahasiswa 
Calon Guru Matematika. Jurnal Kependidikan, 16 (1), 48-58. Retieved from http://lppm.ikipmataram.ac.id/wp-content/uploads/2017/02/Ita-Chairun-NissaYuntawati.-Pengaruh-Pembelajaran-Self-Questioning-dengan-Scaffolding.-JK-Mar2017-Vol-16-No-1.pdf

Quaglia, Russell J. and Fox, Kristine M. (2011). Student Aspiration. Research Press. www.researchpress.com

Sugiyati, S. (2016). Pengaruh Media Pembelajaran dan Minat Belajar Terhadap Hasil Belajar Matematika. Jurnal Penelitian dan Penilaian Pendidikan, 1 (2), 227-241.Retieved from https://www.google.com/search?client=firefox-b$\mathrm{d} \& \mathrm{q}=$ Sugiyati\%2C + S. $+\% 282016 \% 29 .+$ Pengaruh+Media+Pembelajaran+dan+Minat + Belajar+Terhadap+Hasil+Belajar+Matematika.+Jurnal+Penelitian+dan+Penilaian+Pe ndidikan\%2C+1+\%282\%29\%2C+227-241

Wahyudi, A. A. \& Hadaming, H. (2019). Penerapan Strategi Pembelajaran Circuit Learning terhadap Hasil Belajar Matematika Siswa Kelas VI SD Negeri Bawakaraeng 1 Makasar. Jurnal Kajian Pendidikan Dasar, 4 (1), 582-590. Retieved from https://journal.unismuh.ac.id/index.php/jkpd/article/view/1723/1381

Widdiharto, Rachmadi. (2011). Diagnosis Kesulitan Belajar Matematika SMP dan Alternatif Proses Remidinya. Yogyakarta: P4TK Matematika. Retieved from http://p4tkmatematika.org/file/PRODUK/PAKET\%20FASILITASI/SMP/Diagnosis\% 20kesulitan\%20belajar\%20matematika\%20SMP.pdf

Yuntawati, Y. (2017). Efektifitas Scaffolding Terhadap Peningkatan Kemampuan Penyelesaian Masalah Matematika. JIME, 3 (1), 460-465. Retieved from http://ejournal.mandalanursa.org/index.php/JIME/article/view/190/181 